\title{
Effect of Depth on the Growth and Carrageenan Content of Seaweed Kappaphycus alvarezii Cultivated Using Verticulture Method
}

\author{
Petrus Rani Pong-Masak ${ }^{1}$ and Nelly Hidayanti Sarira ${ }^{1 *}$ \\ ${ }^{1}$ Seaweed Cultivation Research Center, 96265 Boalemo Regency, Gorontalo Province, Indonesia
}

\begin{abstract}
Seaweed of Kappaphycus alvarezii is generally cultivated by the long line method through the water surface. The verticulture method might be an alternative method by using water column. This research aimed to evaluate the effects of depth on the growth and carrageenan content of $K$. alvarezii which was cultivated vertically. Cultivation was carried out in the floating raft $(10 \times 10 \mathrm{~m})^{2}$ contained of 36 vertical nets. The size of each net was $5 \times 2 \mathrm{~m}^{2}$ whereas the depth was $0.2,1,2,3,4$, and $5 \mathrm{~m}$. Seaweed seedlings of $50 \mathrm{~g}$ was each tied to the vertical nets; the distance between the knot was $20 \mathrm{~cm}$. The results showed that the depth was significantly different to the daily growth rate of $K$. alvarezii $(\mathrm{p}<0.05)$ but did not affect carrageenan content $(\mathrm{p}>0.05)$. Therefore, this method might be applied as an alternative method to optimally increase seaweed production in narrow area without affecting seaweed quality.
\end{abstract}

\section{Introduction}

The type of red seaweed (Rhodophyceae) becomes the main commodity in fisheries and marine sector of Indonesia. One of the most important seaweed species is Kappaphycus alvarezii for its kappa-carrageenan content. Carrageenan is commonly used as stabilizer, gelling agent, emulsifier, and many more. Hence, these properties are utilized in many industries, such as food, pharmaceutical, cosmetic, textile, paint, toothpaste, and other industries [1,2]. Kappa-carrageenan in K. alvarezii seaweed produces stronger/thicker gelling agent, thus it costs higher and becomes the main commodity that generates foreign exchange for Indonesia [3].

Market demand for carrageenan continues to increase considering its important role in the industry $[4,5]$. To meet the market needs, the effort to trigger the productivity of K.alvarezii as carrageenan source in terms of quantity, quality, and sustainability is needed. Until today, seaweed is mostly cultivated using long-line method. However, applying this method means that seaweed farming is performed only on the water surface, while seaweed is ecologically able to grow in the water column on the condition that it still receives sunlight to perform photosynthesis. Moreover, conflict on water territory concerning seaweed cultivation occurs very often in the central area of seaweed farming development. For instance, if the long-line construction is too long then the shipping lane is hindered.

One of the solutions to overcome the problem is the development of verticulture method. The technique involves the use of rope as instrument to tie seaweed seeds vertically at certain *Corresponding author: nellyhidayantisarira@gmail.com 
depth in the water column that acts as the media until the water transparency limit [6]. The focus of this method is land optimization and water column use. Application of this method is expected to intensify land use and increase seaweed production.

Study concerning seaweed farming by using verticulture method continues to be developed, such as construction model of instrument in the form of vertical rope $[7,8,9,10,11,12]$. Furthermore, other studies that only focused on the aspect of increasing seaweed growth in weight was also reported [13].

It was found that $K$. alvarezii seaweed cultivated in the depth of 0.3-5 m using verticulture method in Barru Regency of South Sulawesi was only able to grow optimally at the depth of 1-4 m [7], while a study conducted by [12] showed that $K$. alvarezii seaweed farmed at the depth of 0.5-2 m in Pangkep Regency grew optimally at the depth of 1-1.5 m. Moreover, other study carried out by [10] indicated that seaweed cultivated at the depth of $0.3-1.5 \mathrm{~m}$ in Boalemo Regency of Gorontalo did not grow optimally, in fact it was vanished since the ocean current velocity was not strong enough to remove epiphytes and mud stuck to the thallus. In spite of the low current velocity in Boalemo Regency $(0.1-0.2 \mathrm{~m} / \mathrm{s})$, it caused the vertical rope that tied the seaweed seeds got tangled and detached from the knot. It concluded that verticulture method is location-specific method and development of its technical application is needed to be adjusted to other areas with strong current.

The objective of this study is to investigate the effect of depth on the growth and carrageenan content of seaweed cultivated using verticulture method by using vertical net.

\section{Methods}

This study was conducted in March-June 2015 in coastal area of Doda Bahari Village, Sangia Wambulu Sub-district, Central Buton Regency, Province of Southeast Sulawesi. Analysis of water quality and carrageenan content was performed in the Laboratory of BPPBAP Maros, South Sulawesi.

\subsection{Preparation of seed}

The seeds of $K$. alvarezii used in this study were obtained from local seaweed farmers. Seaweed seeds selected by the freshness and free from other seaweed species. The seeds were cleaned from dirt or biofouling organism, chopped and weighed for $50 \mathrm{~g} / \mathrm{clump}$.

\subsection{Method of planting}

Floating raft made from wooden beam of $10 \times 10 \mathrm{~m}^{2}$ used in this verticulture method. The construction was equipped with styrofoam floater and concrete anchor as barrier, thus it remained stable and would not be carried away by ocean currents.

Seaweed seeds were tied to polyethylene rope formed into net of $5 \times 2 \mathrm{~m}^{2}$. Vertical net was equipped with ballast concrete-filled PVC pipe with distance between net strands of $1 \mathrm{~m}$. The vertical net consisted of 11 vertical straps and 26 horizontal straps (Figure 1). 

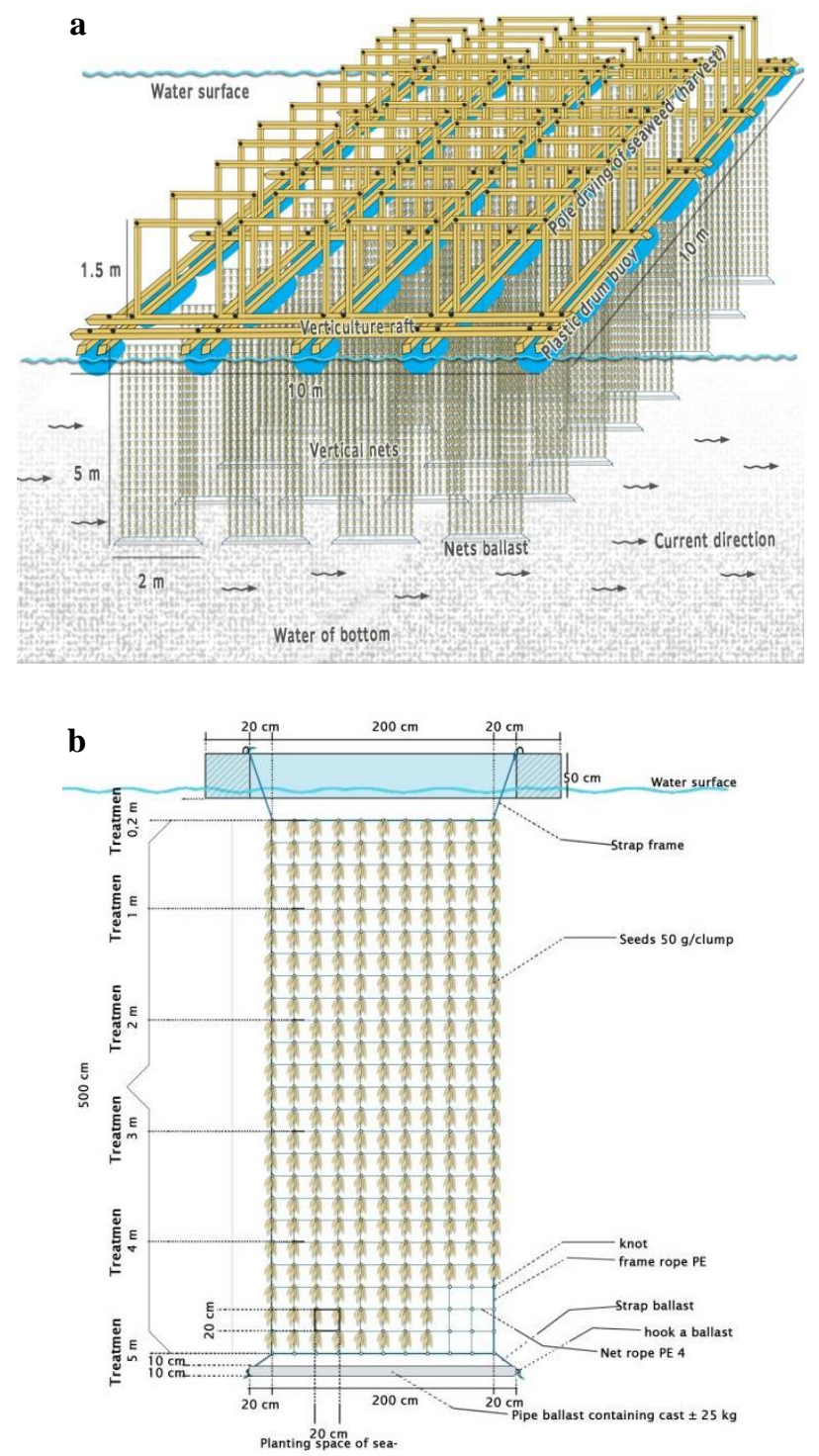

Fig 1. Construction of seaweed culture using verticulture method with vertical net application (a) full view and (b) side view.

At each point where vertical and horizontal ropes met, a knot was made so that rope ring to tie the seaweed seeds could be placed. The distance between knots was $20 \mathrm{~cm}$, thus one vertical rope contained 26 points of seaweed clump and one horizontal rope consisted of 11 points of seaweed clump. Therefore, each net consisted of 286 points of seaweed clump.

One verticulture construction of $10 \times 10 \mathrm{~m}^{2}$ consisted of 36 nets, thus one construction contained 10,296 clumps. Among 36 verticulture nets, 18 nets were tagged and placed randomly for sampling purpose. Rearing period was performed for 3 cycles, each cycle was conducted for 30 days. 


\subsection{Observation}

Observation of seaweed growth and carrageenan content was conducted at the beginning of stocking and $30^{\text {th }}$ day after culture period. Moreover, water quality observation for parameter such as temperature, salinity, ocean current velocity, nitrate, phosphate, and total organic matter (TOM) measured every 15 days.

\subsection{Method for carrageenan analysis}

Harvested seaweed was sun-dried then weighed for $20 \mathrm{~g}$ each sample. The dry seaweed then washed to remove the salt and other polluters. Thereafter, it was extracted on $90-95{ }^{\circ} \mathrm{C}$ using $\mathrm{KOH}$ for 30 minutes with comparison of solvent and raw material $40 \mathrm{~mL}: 1 \mathrm{~g}$ until $\mathrm{pH}$ of the solution reaches 8-9. The result of extraction then deposited in $100 \mathrm{~mL}$ of isopropyl alcohol and stirred then incubated for 15 minutes. The precipitate is dried in $50-60^{\circ} \mathrm{C}$ oven for 3 days. The result then milled and sifted with mesh filter (size 80). Carrageenan that has been obtained then calculated for the content. Carrageenan content is the extract result which is calculated based on the ratio between carrageenan content with the weights of dry sample used in each treatment [14].

$$
\text { Rendemen }(\%)=\frac{\text { Carrageenan weight }}{\text { Seaweed weight }} \times 100
$$

\subsection{Daily growth rate}

Seaweed growth is determined by calculating the daily growth rate (DGR) using the following formula [15]:

Description:

$$
D G R=\left\{\frac{\ln \ln W_{t}-\ln W_{0}}{t}\right\} \times 100 \%
$$

DGR = Daily growth rate $(\% /$ day $)$

$\mathrm{W}_{t} \quad=$ Final weight at time- $t(\mathrm{~g})$

$\mathrm{W}_{o} \quad=$ Initial weight $(\mathrm{g})$

$\mathrm{t} \quad=$ Culture period (day)

\subsection{Data analysis}

Effect of each treatment on observed variables was analyzed with Analysis of Variance (ANOVA) using SPSS (Ver. 16.0) program. If the result was significantly different, Tukey's test at a confidence level of $95 \%$ was further applied.

\section{Result and discussion}

\subsection{Quality of water environment}

The condition of water quality is an important factor that has to be considered in seaweed cultivation since water is the media that directly affects seaweed farming activity. Parameter of water quality that influences seaweed growth includes temperature, salinity, ocean current velocity, and nutrient [16]. Based on the measurement result of water quality parameter during $K$. alvarezii seaweed cultivation, the condition of water quality in the waters of Doda Bahari Village was in range for seaweed farming (Table 1). 
Table 1. Parameter of water environmental quality

\begin{tabular}{|c|c|c|c|c|c|c|}
\hline $\begin{array}{c}\text { Depth } \\
(\mathrm{m})\end{array}$ & $\begin{array}{c}\text { Temperature } \\
\left({ }^{\circ} \mathrm{C}\right)\end{array}$ & $\begin{array}{c}\text { Salinity } \\
(\mathrm{ppm})\end{array}$ & $\begin{array}{c}\text { Ocean } \\
\text { Current } \\
\text { Velocity } \\
(\mathrm{m} / \mathrm{s})\end{array}$ & $\begin{array}{c}\text { Nitrate } \\
(\mathrm{mg} / \mathrm{L})\end{array}$ & $\begin{array}{c}\text { Phosphate } \\
(\mathrm{mg} / \mathrm{L})\end{array}$ & $\begin{array}{c}\text { Total Organic } \\
\text { Matter }(\mathrm{mg} / \mathrm{L})\end{array}$ \\
\hline 0.2 & $29.8-30.3$ & $34-35$ & $0.4-1.0$ & $0.03-0.26$ & $0.07-0.09$ & $29.40-42.54$ \\
\hline 1 & $29.2-30.0$ & $34-35$ & $0.4-1.0$ & $0.02-0.46$ & $0.05-0.11$ & $38.16-58.18$ \\
\hline 2 & $29.0-29.8$ & $34-35$ & $0.4-1.0$ & $0.03-0.25$ & $0.04-0.07$ & $40.04-64.44$ \\
\hline 3 & $29.1-29.6$ & $34-35$ & $0.4-0.9$ & $0.15-0.24$ & $0.04-0.06$ & $36.91-63.81$ \\
\hline 4 & $28.9-29.5$ & $34-35$ & $0.3-0.9$ & $0.17-0.19$ & $0.07-0.08$ & $40.66-63.19$ \\
\hline 5 & $28.6-29.2$ & $34-35$ & $0.3-0.6$ & $0.22-0.24$ & $0.06-0.08$ & $40.66-52.55$ \\
\hline
\end{tabular}

The range of temperature was relatively different in each column, the deeper the water column, the lower the temperature (Table 1). This finding caused by the different sunlight exposure received in each column. The temperature during the study was in a range of 28.6$30.3{ }^{\circ} \mathrm{C}$, while temperature tolerated by $K$. alvarezii seaweed is $26-30{ }^{\circ} \mathrm{C}$ [17].

Salinity measured in each water column during the study found to be similar in range of 34-35 ppt. According to [18], K. alvarezii is seaweed species that is not resistant to high salinity (stenohaline). Concentration of salinity suitable for seaweed growth ranges of 28-35 ppt.

Location for seaweed farming should be protected from ocean currents (water movement) and strong wave because these two factors will destroy and sweep away seaweed. This condition will facilitate change and absorption of nutrient required by plants, but will not cause plant damage [6]. Measurement result for ocean current velocity during the study was $0.3-1 \mathrm{~m} / \mathrm{s}$.

Nitrate is the main form of nitrogen in natural waters. Nitrate is one essential nutrient compound in protein synthesis of animal and plant. High nitrate concentration in waters may stimulate the growth and development of aquatic organism if supported by nutrient availability. Result of nitrate measurement during the study ranged between $0.02-0.46 \mathrm{mg} / \mathrm{L}$. Therefore, this nitrate concentration is considered suitable for the growth of $K$. Alvarezii seaweed. According to [19], the range of nitrate value for seaweed farming of $0.1-0.7 \mathrm{mg} / \mathrm{L}$ is characterized as excellent; $0.01-<0 \mathrm{mg} / \mathrm{L}$ is good, and $<0.01 \mathrm{mg} / \mathrm{L}$ is considered poor. Phosphate concentration during the study ranged from $0.04-0.11 \mathrm{mg} / \mathrm{L}$, which still in range the value tolerated by seaweed. Optimum range of phosphate for seaweed growth is $0.02-1.0$ $\mathrm{mg} / \mathrm{L}[20]$.

\subsection{Seaweed Growth}

$K$. alvarezii seaweed cultivated with verticulture method at a depth of $0.2 \mathrm{~m}$ obtained the highest DGR of 5.6\%/day, while the lowest was found at $5 \mathrm{~m}$ depth of $2.2 \% /$ day (Figure 2). This result is caused by the different environmental conditions. Seaweed in each water column requires different sunlight intensity to be used as an energy source for photosynthesis 
process. Different photosynthesis leads to different seaweed ability in each water column to obtain nutrient that will affect seaweed growth. Moreover, relatively different water movement or ocean current in each water column also affects nutrient absorption from seawater to seaweed thallus that correlates with seaweed growth

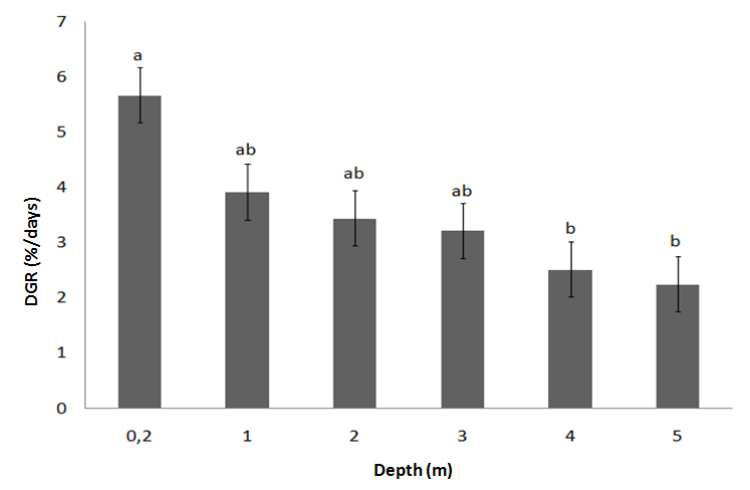

Fig 2. Effect of depth on daily growth rate of Kappaphycus alvarezii seaweed

Compared to 4-5 m depth, seaweed at a depth of 0.2 m was more exposed to sunlight as an energy source for photosynthesis process. This correlates with thermal stratification. At a depth of $0.2 \mathrm{~m}$, temperature range of $29.8-30.3^{\circ} \mathrm{C}$, while at $5 \mathrm{~m}$ depth, the range of temperature was about $28.6-29.2^{\circ} \mathrm{C}$. Hence, deeper water means lower temperature.

Moreover, compared with ocean current at 4-5 m depth that ranged of 0.3-0.6 m/s, there was stronger water movement at $0.2 \mathrm{~m}$ depth of $0.4-1.0 \mathrm{~m} / \mathrm{s}$. Besides cleaning particles attached to seaweed thallus, ocean current also contains nutrients that will be absorbed by seaweed. Optimal photosynthesis process and ocean current facilitate seaweed to obtain nutrient for its growth, resulted in high DGR. Therefore, transparency and current velocity become the determining factor in seaweed farming with verticulture method. Similar result was reported by [21] that extremely low sunlight intensity will hinder seaweed growth since photosynthesis process will not be completely performed. Nutrient absorbed in seaweed cells and the release of metabolic residue will be hindered if seaweed is grown too deep or in area with less water movement.

DGR of seaweed at 0.2-3 m depth in this study was categorized optimal since the growth value is higher than $3 \%$ /day [22]. This may be caused by the condition of waters that was quite fertile with concentration of nitrate of $0.15-0.46 \mathrm{mg} / \mathrm{L}$, phosphate of $0.04-0.11 \mathrm{mg} / \mathrm{L}$, and DOM of 29.40-64.44 mg/L (Table 1). According to [23], water that contains total organic matter above $26 \mathrm{mg} / \mathrm{L}$ is considered fertile.

Seaweed at $5 \mathrm{~m}$ depth was still able to grow well since water transparency in farming location was quite high, thus sunlight could penetrate into $14 \mathrm{~m}$ depth or around $50 \%$ of total depth of waters. Therefore, seaweed located close to the sea surface or up to $5 \mathrm{~m}$ depth were still reached by sunlight as energy source to perform photosynthesis. Water transparency influences sunlight penetration to the seawater. According to [24] and [25], transparency becomes an important factor that is related to the availability of sunlight for photosynthesis, thus seaweed farming should be performed in waters where sunlight is able to penetrate up to $5 \mathrm{~m}$ depth, at minimum. Turbid waters contain much fine particles that will attach to seaweed thallus and further inhibit food absorption and photosynthesis process.

Based on Figure 4, it is known that DGR of seaweed was not significantly different $(p>0.05)$ at a depth of $0.2,1,2$, and $3 \mathrm{~m}$, but it was statistically different $(\mathrm{p}<0.05)$ at a depth of 4 and $5 \mathrm{~m}$. It shows that seaweed cultivated using verticulture method in research location should be performed at $0.2-3 \mathrm{~m}$ depth to obtain optimal result. 


\subsection{Carrageenan Content}

Seaweed cultivated through verticulture method contained quite fluctuated carrageenan content at each depth. $K_{-}$alvarezii cultured at $5 \mathrm{~m}$ depth obtained the highest carrageenan content of $36.6 \%$, while the lowest was obtained at $1 \mathrm{~m}$ depth of $27.6 \%$ (Figure 3). This finding is caused by environmental conditions such as salinity, phosphate, and DOM that obtained quite similar value in each water column (Table 1). Furthermore, it is also expected that seaweed at $5 \mathrm{~m}$ depth is protected from sunlight exposure that has a negative effect, i.e. UV radiation to carrageenan content of seaweed. According to [26], the quantity and quality of carrageenan produced from mariculture varied due to variety or species difference, age of planting, sunlight intensity, temperature, nutrients, and salinity.

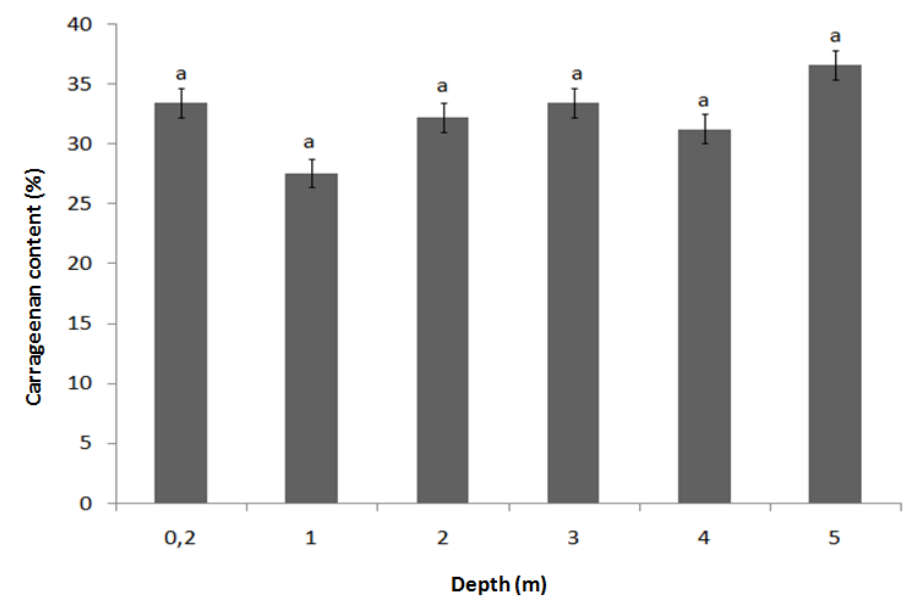

Fig 3. Carrageenan content of Kappaphycus alvarezii seaweed

It is known that carrageenan content of seaweed was not significantly different $(p>0.05)$ among the treatment of $0.2,1,2,3,4$, and $5 \mathrm{~m}$ depth (Figure 3 ). It indicates that carrageenan content is not affected by depth, thus verticulture method can be applied as an alternative method to increase seaweed production in narrow area without affecting seaweed quality, carrageenan wise.

\section{Conclusion}

Depth affected the growth of $K$. alvarezii but it did not affect the carrageenan content of seaweed cultivated with verticulture method. This method can be applied as an alternative method to optimally increase seaweed production in narrow area without affecting seaweed quality.

\section{Acknowledgement}

The author would like to thank to the representative Tasks Executor of the Regent and DKP of Central Buton Regency, field technician (Yohannes Teken, Rifka Pasande, Aditia Farman, and Handy Burase), and seaweed farmer group of Doda Bahari who have supported the execution of this research. The author also would like to thank Prof. Dr. Ir. Myrtha Karina, M.Agr for providing guidance during the research writing. 


\section{References}

1. Wenno, M.R., J.L. Thenu and C.G.C. Lopulalan. Characteristics of Kappa carrageenan from Kappaphycus alvarezii at various harvest ages. JPB Perikanan 7 (1): 61-67 (2012).

2. Bunga, S. M., R. I Montolalu, J. W. Harikedua, L. A. D. Y. Montolalu, A. H. Watung, and N. Taher. Characteristic of physical chemical seaweed Kappaphycus alvarezii at various age of harvest taken from thewater of Arakan Village, South Minahasa Regency. Jurnal Media Teknologi Hasil Perikanan 1 (2): 54-58 (2013).

3. Sulistiani, E \& Samsul, A.Y. Tissue culture of seaweed (Kappaphycus alvarezii). Bogor: SEAMEO BIOTROP. 128 p (2014).

4. Harun, M., R.I Montolalu, and I.K., Suwetja. Characteristic of physical chemical seaweed Kappaphycus alvarezii at various age of harvest taken from thewater of Tihengo Village, Gorontalo Utara Regency. Jurnal Media Teknologi Hasil Perikanan 1 (1): 7-12 (2013).

5. Utojo, A. Mansyur, B. Pantjara, A.M. Pirzan, and Hasnawi. Environmental conditions The waters of Mallasora Bay are suitable for the location of the development of seaweed cultivation (Eucheuma sp.). Jurnal Riset Akukultur 2 (2): 243-55 (2007).

6. Pong-Masak, P.R and N.H. Sarira. 2016. Growth and production of Kappaphycus alvarezii seaweed by verticulture method. Prosiding Forum Inovasi Teknologi Akuakultur, 449-56 (2016).

7. Pong-Masak, P.R and M. Tjaronge. Growth performance and carrageenan content of seaweed Kappaphycus alvarezii with the application of verticulture cultivation methods. Final Report by BRPBAP, KKP (2009).

8. Pongarrang, D., A. Rahman, and W. Iba. Effect of spacing and weight of seedlings on the growth of seaweed (Kappaphycus alvarezii) using the verticulture method. Jurnal Mina Laut Indonesia 3 (12): 94-112 (2013).

9. Syahlun, A. Rahman, and Ruslaini. Seaweed growth test (Kappaphycus alvarezii) brown strain with verticulture method. Jurnal Mina Laut Indonesia 1 (1): 122-32 (2013).

10. Pong-Masak, P.R and D.A. Pratiwi. Dissemination of seaweed cultivation with verticultural methods. Final Report by LRBRL, KKP (2014).

11. Widowati, L.L, S. Rejeki, T. Yuniarti and R.W. Ariyati. Efficiency of E. cotonii seaweed production using vertical long line cultivation methods as an alternative to the use of water columns. Jurnal Saintek Perikanan 11 (1): 47-56 (2015).

12. Nursidi, M and Heriansah. Development of seaweed Kappaphycus alvarezii cultivation through vertical method in the water of small islands in South Sulawesi, Indonesia. AACL Bioflux 10 (6): 1428-35 (2017).

13. Hendri, M., Rozirwan, R. Apri, and Y. Handayani. Intensification of seaweed cultivation Euchema Ccottonii with verticulture method in the water of Kelagian Island, Lampung Bay. International Journal of Marine Science 8 (14): 114-26. https://doi.org/10.5376/ijms.2018.08.0014 (2018).

14. FMC Corp. Carrageenan, marine colloid monograph number one. Springfield, New Jersey. USA Marine Colloids Division FMC Corporation 23-29 p (1977).

15. Hung, L.D., K. Hori, H.Q. Nang, T. Kha, and L.T. Hoa. Seasonal changes in growth rate, carrageenan yield and lectin content in the red alga Kappaphycus alvarezii cultivated in Camranh Bay, Vietnam. Journal of Applied Phycology 21: 265-72. https://doi.org/10.1007/s10811-008-9360-2 (2019). 
16. Rasyid, A. Comparison of the quality of sodium alginate in some types of brown algae. Oseanologi danLimnologi di Indonesia, 35(1): 56-64 (2009.).

17. Anggadiredja, J.T., Zatnika, A., Purwoto, H., and Istini, S. Seaweed. Jakarta: Penebar Swadaya. 147 p (2011).

18. Sudradjat, A. Cultivating 23 marine commodities is profitable. Jakarta: Penebar Swadaya. 153 p (2008).

19. Munaeni, W.O. The growth and carrageenan content of several different types of seaweed Kappaphycus alvarezii with different thallus colors are maintened in rocky waters. Essay. Universitas Haluoleo (2011).

20. Guo, H., Y. Jianting, Z. Sun, and D. Duan. Effects of salinity and nutrients on the growth and chlorophyll fluorescence of Caulerpa lentillifera*. Chinese Journal of Oceanology and Limnology 33 (2): 410-18. https://doi.org/10.1007/s00343-015-4105-y (2015).

21. Syahlun, A. Rahman, and Ruslaini. Seaweed growth test (Kappaphycus alvarezii) brown strain with verticulture method. Jurnal Mina Laut Indonesia 1 (1): 122-32 (2013).

22. Ask, Erick I, and R.V. Azanza. Advances in cultivation technology of commercial eucheumatoid species: a review with suggestions for future research. Aquaculture $\mathbf{2 0 6}$ (2002): 257-77 (2002).

23. Reid, G.K. Ecology of inland waters and estuaries. Reinhold Publisher. New York, 396 pp (1961).

24. Yuniarsih, E., K. Nirmala and I.N. Radiarta. The level of nitrogen and phosphorus absorption in IMTA (integrated multi-trophicaquaculture) based seaweed cultivation in Gerupuk Bay, Central Lombok, West Nusa Tenggara. Jurnal Riset Akukultur 9 (3):487500. https://doi.org/10.15578/jra.9.3.2014.487-500 (2015).

25. Kamlasi, Y. Ecological and biological studies for the development of seaweed (Eucheuma cottonii) in West Kupang District, Kupang Regency, East Nusa Tenggara Province. Essay. IPB (2008).

26. Hayashi, L., E.J.D. Paula, and F. Chow. Growth Rate and carrageenan analyses in four strains of Kappaphycus alvarezii (Rhodophyta, Gigartinales) farmed in the subtropical waters of Sao Paulo, Brazil. Journal of Applied Phycology 19: 393-99. https://doi.org/10.1007/s10811-006-9135-6 (2007).

27. Pong-Masak, P.R. and H. Burase. Construction of seaweed culture using verticulture method with vertical net application (a) full viewand (b) side view. LRBRL, BRSDM $K K P(2015)$. 